\title{
Influence of the methodology for evaluating energy performance of buildings over the energy needed for cooling
}

\author{
A. Galiano \& V. Echarri \\ Department of Building Technology, University of Alicante, Spain
}

\begin{abstract}
The need to reduce energy bills and the need for protection for the user has made the government of Spain develop new regulations that reinforce thermal isolation requirements. The adopted methodology for evaluating energy performance in buildings is based on informatics tools, where it is difficult to check the measures for improving energy efficiency work. The objective of this paper is to compare the current methodology for evaluating energy needed for cooling in Spain with the methodologies of some European countries. The research is based on applying those methodologies over a case study conducted on the Mediterranean coast of Spain (warm conditions), applying different U-limits and evaluating the obtained energy needed for cooling from each method. The results show that improving constructive solutions and increasing thermal isolation thickness in some cases do not offer the expected results as the energy needed for cooling raises especially in methodologies belonging to cold countries.

Keywords: U-limits, transmittance, EPBD, energy performance, cooling, isolation.
\end{abstract}

\section{Introduction}

The process for approving the Código Técnico de la Edificación (CTE Technical Building Code) [1] and bringing it into force has, from a regulatory point of view, led to a very significant change in the sphere of the construction industry in Spain. The old prescriptive regulations have disappeared, giving way to performance-based texts. The old criteria and solutions have given way to minimum quality requirements whereby the designers or planners must indicate the most appropriate solution. The Documento Básico Ahorro de Energía (DB 
HE - Basic Energy Saving Document) indicates for the first time a procedure for a full check on the energy performance of buildings, something that is a true novelty in Spain, which has to date only had a symbolic presence in projects.

The European Union's (EU) requirement of adaptation to the Energy Performance of Buildings Directive (EPBD) [2] is what has motivated the Spanish Government to make the conditions that need to be complied with in the matter of energy savings in buildings more stringent. To date, the Government's permissiveness had been justified by the favourable climatic conditions in a large part of the country and by the absence of energy demand for cooling.

The calculation of energy demand and obtaining the energy certification is proposed through two computer programs, LIDER and CALENER, recently updated into one unified program called LIDER-CALENER, which are characterised by being opaque and not very didactic. The characteristics of the process and the manner in which the building is positioned in the energy scale offers doubts as to the viability of the measures for encouraging the saving of energy [3].

The proliferation of individual air-conditioning equipment in flats and houses and, therefore, the existence of an increase in the energy demand for cooling purposes, justify an analysis of the energy performance of buildings in summer. The approval of (EU) Regulation $N^{\circ}$ 244/2012 [4], by which the investment in measures to promote the saving of energy needs to be justified, requires that a check be made on the viability of constructive improvements and on their repercussions on the energy performance of buildings both in winter and in summer.

\section{Motivation of the investigation}

The situation in Spain shows that the CTE has remained essentially unaltered since it was approved in 2006, although the DB HE was recently modified. In 2013 the process of implementation of EPBD 2002/91/CE was deemed to have been finalised with the approval of the existing energy certification of buildings [5]. Both the methodology for the evaluation of the energy performance of buildings and the constructive demands required by the Government of Spain with regard to energy saving measures, transmittance factors amongst others, have remained unaltered for a long time. On the other hand, in Europe the speed of implementation of the EPBD has been greater, as has the increase in constructive demands aimed at improving the energy performance of buildings.

The difficulties found in the procedures for the evaluation of energy and energy certification in Spain, which cast doubt on the identification of factors such as design in the energy performance of buildings [6], justify a study into the evaluation of the impact of constructive improvements in the energy performance of buildings. The increase in energy demand in periods of cooling justify the election of this period of time, it also being of interest to position the aforementioned regulation within the spectrum of methodologies adopted by the remainder of countries in the European Union and to analyse the impact of said constructive improvements at the same time. 


\section{Methodology of the investigation}

A method of working is proposed that is based on the comparison of energy evaluation and certification material from amongst the procedures that are current in Spain and the methodologies in certain countries in the European Union, considered to be representative, through their application to a case study located in a place with a climate that generates the greatest energy demand in summer.

The successive application of the regulations is applied to a case that is the object of the study, varying the limits of the transmittance factor (U). The limits of the U-factor adopted in the comparison are as follows:

- Those currently in use in Spain.

- Those currently in use in countries whose regulations are being compared.

- The optimum factors recommended by the European Insulation Manufacturers Association (EURIMA) [7].

The successive application of the methodologies selected, with the variation in the limits of the transmittance factor and applied to the same case study, enables us to evaluate the following factors in a comparative manner:

- The influence on the interchange of energy through the insulating material as a result of the increase in the requirements of the transmittance factor.

- The percentage improvement of overall energy demand resulting from the variation of the interchange of energy through the insulating material.

The results of the investigation will enable the positioning of the Spanish regulations currently in force within the spectrum of the remainder of the regulations. In this way, we can find out the degree of objectivity in the matter of the calculation of the energy required for cooling purposes in the Spanish regulations, compared to that in the remainder of the countries. It will also be possible to establish the compared impact of the improvements in construction on the energy required for cooling purposes by the different methods.

\section{Selection of the representative methodologies from amongst those in use in EU countries}

The analysis of the methodologies for the evaluation and certification of energy performance of buildings in EU countries shows a great variety of situations, despite setting out from a common starting point and having as a guide the norms developed by the European Committee for Standardisation (CEN) [8]. In some cases these situations are extremely complex, such as the case of Italy, where there are almost as many procedures as there are provinces and regions in the country.

The freedom that the EPBD grants each member country of the EU has generated the establishment of objective limits, such as the consumption of energy or $\mathrm{CO}_{2}$ emissions, or subjective ones, such as the comparison with an object building or with the average of buildings constructed at a particular time, in order to obtain the energy certification. 
From a political point of view, the intentions of the different governments are shown through two crucial factors for evaluating the performance of a building: the strengthening of factors that reduce the consumption of energy and the form in which the different methodologies give a weighting to the sources of energy once the overall demand of the building has been calculated. Likewise, it is possible to identify through the regulations the regime or season during which there is greatest demand, winter or summer, depending on the prevailing climate of the country.

From the analysis of the different methods it is possible to affirm that, in some climatic areas, the subjective type of conditioning factors have, in the process of implementing the EPBD, an importance similar to that of the conditions of a physical nature [9].

Amongst the range of procedures that the different EU countries have adopted for the evaluation of the energy performance of buildings, we have opted to classify them on the basis of the following parameters:

- Tradition in the development of methods for evaluating the energy performance of buildings and harmonisation with the regulations defined in the "Umbrella Document" [10].

- Degree of implementation of the EPBD.

- Classification on the basis of the method of evaluation and certification.

- Belonging to a climatic area.

- Definition and evolution of the values of thermal transmittance.

The tradition in the definition of limits of energy demand originates in those countries in which the use of heating is made necessary by the harshness of the winters. Thus, in Europe we can identify a gradient from North to South whereby the Scandinavian countries are pioneers in this process, whereas the countries in the Mediterranean area are the last to adopt regulations to limit the consumption of energy in buildings. The hardening of the limits of the transmittance factor and the adoption of objective methods for classifying the consumption of energy follow the same pattern. It is the countries in the north and centre of Europe that periodically review the constructive limits and that adopt methods of certification that are easy to interpret, in comparison to what happens in southern Europe [11].

Once all of the methodologies currently in use have been classified and analysed, those shown below have been selected as being representative and therefore objects of comparison with the methodology currently in use in Spain.

\subsection{Countries in the North of Europe}

\subsubsection{Finland}

This was the first country to establish a building code. It has a prescriptive method for the calculation of energy demand that goes back to 1976 [12]. They have defined an absolute limit of Primary Energy in order to establish the energy rating. For the purposes of the calculation of the case study, use will be made of that which is set out in Finland's Building Code [13] in its documents C3, D3 and D5. 


\subsubsection{Denmark}

They published their first building code with constructive measures to improve the energy performance of buildings in 1961 [14], introducing a prescriptive method in 1976 for the calculation of energy demand. This is one of the few examples that uses an absolute limit for the energy certification and, in this case, they use Primary Energy as the parameter for establishing the energy rating. The methodology currently in use in Denmark is based on the Building Code [15] and on Regulation SBi 213 [16].

\subsection{Countries in Central Europe}

\subsubsection{Germany}

Since 1976 they have had a specific Law to limit the consumption of energy in buildings [17]. They have adopted a comparative fixed-reference method, using Primary Energy, Final Energy and $\mathrm{CO}_{2}$ emissions as the parameters for establishing the energy rating. The procedure is based on that which is indicated in Regulation EnEV 2009 [18] and in the regulatory series DIN V 18599:2007 [19].

\subsubsection{Holland}

This is one of the countries with a tradition in the energy certification of buildings that has taken longest to adapt to the EPBD, given that they had their own regulations that dealt with this matter [20]. They adopted a comparative fixed-reference method using a dimensionless factor that depends on the Consumption of Primary Energy and on the efficiency of the installations. For the calculation we will use that which is defined in the General Construction Code [21] and in the specific regulations: NEN 5128 [22], NEN 2916 [23], NEN 7120 [24] and NVN 7125 [25].

\subsection{Countries in the South of Europe}

\subsubsection{Italy}

This is one of the countries that has taken longest to adapt to the EPBD due to the lack of commitment of the provinces and regions. This led the Central Government to publish regulations on a national level in 2010. They define a comparative fixed-reference method using Primary Energy, Final Energy and $\mathrm{CO}_{2}$ emissions as parameters for establishing the energy rating. For the calculation we will use National Regulation UNI TS 11300 [26].

\subsubsection{Portugal}

They have had a prescriptive method since 2000. It defines a comparative fixedreference method, which uses Primary energy and $\mathrm{CO}_{2}$ emissions as parameters for establishing the energy rating. The limit is obtained by comparison with a building in which the consumption has been defined by the directives established by the Government. To carry out the calculation we will use that which is set out in Regulation RCCTE [27]. 


\section{Case study}

In order to carry out the present investigation we have taken as a reference an isolated residential building used as a collective dwelling block. It has a ground floor, three upper storeys and a basement used as a car park. This is considered to be a very common type of building in Spain and in the remainder of countries in Europe and could be considered to be representative of Spanish housing offered. The size of the dwellings, the number of rooms and the composition mean that they can be classed as a common standard for an average-size family in Spain. The location chosen is Alicante, in the south-east of Spain, on the Mediterranean coast, where the consumption of energy for cooling purposes is predominant. The definition of a specific place for the object of the case study is very important, as the influence has been demonstrated of the location in the process of evaluation of the energy performance of a building [28].
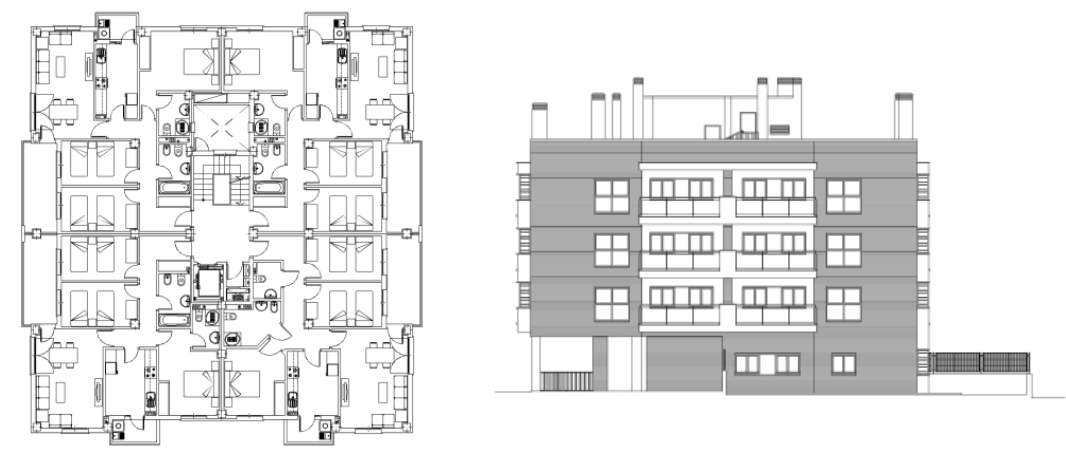

Figure 1: Floor plan and South elevation.

The building has façades looking in four directions and a normal level of exposure, as it is located in a residential neighbourhood surrounded by other buildings with similar characteristics. The building is turned $45^{\circ}$ to geographical North which means that, with its location in Alicante, during the summer months all of the façades will receive natural sunlight at some time of the day. The surrounding land is flat and in the immediate vicinity there are no notable elements that will create direct or indirect shadows over the construction.

The building consists of 14 dwellings arranged as follows: 2 dwellings (Types A and B) on the ground floor and four dwellings per storey on the 3 upper storeys (types A, B, C and D). The remainder of the ground floor is given over to porch or hallway space. As we have previously indicated, the building has a basement, which is used as a car park.

The dwellings are arranged around a central communications nucleus consisting of a stairwell, the lift and a central patio, which allows natural light and ventilation to get through to the inner rooms of the dwellings. 
The façades also have a design that can be considered to be common for this type of building in terms of the size of the apertures, the percentage of same with regard to the total surface area of the façade and its construction.

On a constructive level, it has multi-layer walls with exterior finishing consisting of a brick facing. In this case and given the incompatibility that this would present in other countries, it has been decided to provide continuity to the thermal insulation by the placing of a free-standing external sheet, a type that is rarely seen in the Mediterranean area, as opposed to the common type, being a sheet supported within the framework, which produces significant thermal bridges. The roof is flat, inverted and finished with stoneware paving. In both cases, the thermal insulation is extruded polystyrene.

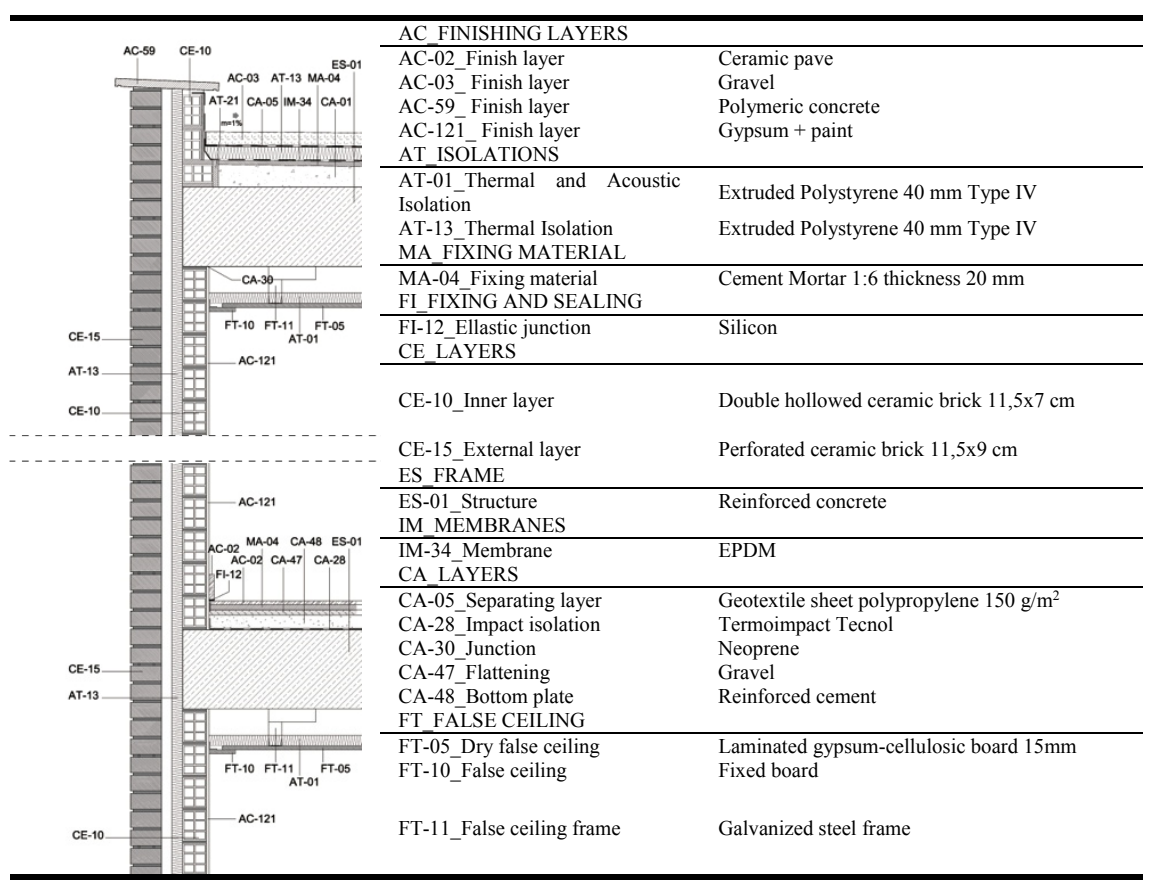

Figure 2: Constructive section and description of materials.

The surfaces of the shell of the case-study building that are in contact with the exterior atmosphere, considered in the calculation, are indicated in Table 1. For the calculation of the internal thermal gains we have taken into account the net habilitated area and the number of occupants (shown in Table 2). 
Table 1: $\quad$ Case study geometrical data.

\begin{tabular}{|c|c|c|c|c|c|c|}
\hline \multicolumn{7}{|c|}{ SURFACE $\left[\mathrm{m}^{2}\right]$} \\
\hline Walls & & $\begin{array}{l}\text { North } \\
\text { facade }\end{array}$ & $\begin{array}{c}\text { South } \\
\text { facade }\end{array}$ & $\begin{array}{c}\text { East } \\
\text { facade }\end{array}$ & $\begin{array}{c}\text { West } \\
\text { facade }\end{array}$ & TOTAL \\
\hline \multirow[t]{2}{*}{ Opaque } & & 223.97 & 211.84 & 202.87 & 205.53 & 844.21 \\
\hline & Brick wall & 223.97 & 211.84 & 202.87 & 205.53 & - \\
\hline \multirow{3}{*}{ Huecos } & & 42.28 & 56.77 & 49.35 & 59.04 & 207.43 \\
\hline & Doors & 19.66 & 31.63 & 25.20 & 34.89 & - \\
\hline & Windows & 22.62 & 25.14 & 24.15 & 24.15 & - \\
\hline \multicolumn{2}{|l|}{ TOTAL } & 266.25 & 268.61 & 252.22 & 264.57 & 1051.64 \\
\hline \multicolumn{2}{|c|}{$\%$ HUECO } & $18.88 \%$ & $26.80 \%$ & $24.33 \%$ & $28.73 \%$ & $24.57 \%$ \\
\hline \multirow{2}{*}{\multicolumn{2}{|c|}{ Roof }} & Pavement & Gravel & Patio & & \\
\hline & & 412.39 & 8.25 & 7.50 & & 428.14 \\
\hline \multirow{2}{*}{\multicolumn{2}{|c|}{ Floor }} & Terrain & External & Non clim & & \\
\hline & & 426.49 & 158.04 & 162.90 & & 747.43 \\
\hline \multicolumn{7}{|c|}{ LENGTH [m] } \\
\hline & & North & South & East & West & TOTAL \\
\hline \multicolumn{7}{|c|}{ Thermal Bridges } \\
\hline & Floor superior & 23.20 & 21.92 & 24.72 & 24.72 & 94.56 \\
\hline & Floor inferior & 23.20 & 21.92 & 24.72 & 24.72 & 94.56 \\
\hline & Lintel & 25.20 & 33.00 & 33.00 & 33.00 & 124.20 \\
\hline & Ledge & 25.20 & 33.00 & 33.00 & 33.00 & 124.20 \\
\hline & Floor edge & 20.52 & 21.92 & 11.05 & 11.05 & 64.54 \\
\hline TOTAL & & & & & & 502.06 \\
\hline
\end{tabular}

Table 2: $\quad$ Inner heat loads calculation data.

\begin{tabular}{|l|l|l|}
\hline Use of the building & Collective residential block & 14 homes \\
\hline Net habilitated area & $1,113^{\prime} 09$ & $\mathrm{~m}^{2}$ \\
\hline Number of occupants & 56 & people \\
\hline
\end{tabular}

\section{Calculation of the thickness of the thermal insulation}

The characteristics of the climate on the Spanish Mediterranean coast would enable compliance with the limits of the transmittance factor established in the DB HE with a thermal insulation thickness of $40 \mathrm{~mm}$.

The application of the different transmittance factors adopted in the study, both those currently in use in the countries with representative methodologies and those recommended by EURIMA, propose insulation thicknesses that in some cases are far greater than those obtained by applying the limits to the transmittance factor currently in use in Spain.

Table 3 shows, according to the EU countries selected, the thermal insulation thicknesses obtained after applying the transmittance factor values adopted for the study. 
Table 3: U-limits and thermal isolation thicknesses.

\begin{tabular}{lccccccc}
\hline & \multicolumn{2}{c}{ Wall } & \multicolumn{2}{c}{ Roof } & \multicolumn{2}{c}{ Floor } & Windows \\
& $\begin{array}{c}\mathrm{U} \\
\mathrm{W} / \mathrm{m}^{2} \mathrm{~K}\end{array}$ & $\begin{array}{c}\mathrm{AT} \\
\mathrm{mm}\end{array}$ & $\begin{array}{c}\mathrm{U} / \mathrm{m}^{2} \mathrm{~K} \\
\mathrm{AT}\end{array}$ & $\begin{array}{c}\mathrm{AT} \\
\mathrm{mm}\end{array}$ & $\begin{array}{c}\mathrm{U} / \mathrm{m}^{2} \mathrm{~K} \\
\mathrm{~mm}\end{array}$ & $\begin{array}{c}\mathrm{U} \\
\mathrm{W} / \mathrm{m}^{2} \mathrm{~K}\end{array}$ \\
\hline Spain & 0.51 & 40 & 0.54 & 40 & 0.66 & 40 & 2.90 \\
Spain EU & 0.40 & 60 & 0.30 & 80 & 0.60 & 50 & 1.20 \\
Denmark & 0.40 & 60 & 0.25 & 120 & 0.30 & 85 & 2.00 \\
Denmark Sp & 0.51 & 40 & 0.54 & 40 & 0.66 & 40 & 2.90 \\
Denmark EU & 0,13 & 250 & 0.10 & 300 & 0.20 & 150 & 1.00 \\
Finland & 0.17 & 170 & 0.09 & 210 & 0.09 & 230 & 1.00 \\
Finland Sp & 0.51 & 40 & 0.54 & 40 & 0.66 & 40 & 2.90 \\
Finland EU & 0.15 & 200 & 0.12 & 250 & 0.20 & 150 & 1.00 \\
Germany & 0.28 & 90 & 0.20 & 160 & 0.28 & 110 & 1.30 \\
Germany Sp & 0.51 & 40 & 0.54 & 40 & 0.66 & 40 & 2.90 \\
Germany EU & 0.13 & 250 & 0.10 & 300 & 0.20 & 150 & 1.00 \\
Italy & 0.34 & 80 & 0.32 & 75 & 0.40 & 80 & 2.10 \\
Italy Sp & 0.51 & 40 & 0.54 & 40 & 0.66 & 40 & 2.90 \\
Italy EU & 0.40 & 60 & 0.30 & 80 & 0.60 & 50 & 1.20 \\
Netherlands & 0.29 & 90 & 0.29 & 90 & 0.29 & 90 & 2.20 \\
Netherlands Sp & 0.51 & 40 & 0.54 & 40 & 0.66 & 40 & 2.90 \\
Netherlands EU & 0.13 & 250 & 0.10 & 300 & 0.20 & 150 & 1.00 \\
Portugal & 1.60 & 0 & 1.00 & 10 & 1.00 & 20 & 3.20 \\
Portugal Sp & 0.51 & 40 & 0.54 & 40 & 0.66 & 40 & 2.90 \\
Portugal EU & 0.40 & 60 & 0.30 & 80 & 0.60 & 50 & 1.20 \\
\hline
\end{tabular}

\section{Calculation of the energy demand for cooling purposes}

The calculation of the energy demand for cooling purposes is looked at in accordance with the considerations made by each of the methodologies selected. Amongst the methodologies selected we have found two methods, other than that currently in use in Spain, that are based on computer programs. These are in Holland and Denmark. The remainder offer the possibility of using either a computer program or spreadsheets. To carry out this study and in order to include the greatest possible number of possibilities, we have opted for selecting the procedures based on spreadsheets.

For the calculation of the energy demand for cooling purposes, the methodologies selected are based, with some qualifications, on the process indicated in EN ISO 13790 [29]. This is a method in which a sequential calculation is made of the different parameters of the energy performance of the building that is being evaluated. The energy required for cooling is obtained from the difference between the energy gains $Q_{C, g n}$ and the energy losses $Q_{C, h t}$, weighted in accordance with the following formula:

$$
Q_{C n d}=Q_{C g n}-\eta_{C g n} \cdot Q_{C h t}
$$

The energy gains $Q_{C, \text { gn }}$ are obtained from adding the internal gains $Q_{C, \text { int }}$ and the gains through exposure to sunlight $Q_{C \text {,sol }}$ according to the following formula: 


$$
Q_{C g n}=Q_{\text {int }}+Q_{\text {sol }}
$$

The energy losses are related principally to the constructive quality of the shell and it is necessary to calculate the losses of energy through transmission $Q_{C, t r}$ and the energy losses through ventilation $Q_{C \text {,ve }}$ in accordance with the following formula:

$$
Q_{C h t}=Q_{t r}+Q_{v e}
$$

The factor $\eta_{C, g n}$ is a dimensionless correction factor resulting from the use of energy losses from cooling.

The results obtained from the application of the different methodologies to the case study are included in Table 4 below, the parameters being:

$Q_{C, g n} \quad$ Total energy gains $\left(Q_{C, \text { int }}+Q_{C, s o l}\right)$.

$Q_{C, t r} \quad$ Loss of heat by transmission through the shell.

$Q_{C, t r+s o l}$ Heat gains by transmission and solar radiation through doors and windows.

$Q_{C, p t} \quad$ Loss of heat by transmission through thermal bridges.

$Q_{C, \text { int }} \quad$ Internal heat gains.

$Q_{C, n d} \quad$ Net energy for cooling.

Table 4: Net energy for cooling.

\begin{tabular}{cccccccc}
\hline Concept & $Q_{C, g n}$ & $\begin{array}{c}Q_{C, t r} \\
\text { Country }\end{array}$ & $\mathrm{kWh} / \mathrm{y}$ & $\begin{array}{c}Q_{C, t r}+ \\
\text { sol } \\
\mathrm{kWh} / \mathrm{y} / \mathrm{y}\end{array}$ & $\begin{array}{c}Q_{C, p t} \\
\mathrm{kWh} / \mathrm{y}\end{array}$ & $\begin{array}{c}Q_{C, \text { int }} \\
\mathrm{kWh} / \mathrm{y}\end{array}$ & $\begin{array}{c}Q_{\text {Cnd }} \\
\mathrm{kWh} / \mathrm{y}\end{array}$ \\
\hline Spa & co & $48,141.43$ & $13,179.63$ & $16,670.45$ & $1,600.21$ & $13,830.89$ & $18,496.29$ \\
& $\mathrm{sp}$ & - & - & - & - & - & - \\
& eu & $48,058.01$ & $12,847.46$ & $16,902.31$ & $1,125.47$ & $14,269.01$ & $18,352.25$ \\
Den & co & $89,536.96$ & 0.00 & 0.00 & 0,00 & $54,274.27$ & $89,536.96$ \\
& sp & $89,536.96$ & 0.00 & 0.00 & 0,00 & $54,274.27$ & $89,536.96$ \\
& eu & $89,536.96$ & 0.00 & 0.00 & 0,00 & $54,274.27$ & $89,536.96$ \\
Fin & co & $173,218.49$ & 0.00 & $76,714.54$ & 0,00 & $61,125.91$ & $173,218.49$ \\
& sp & $173,218.49$ & 0.00 & $76,714.54$ & 0,00 & $61,125.91$ & $173,218.49$ \\
& eu & $173,218.49$ & 0.00 & $76,714.54$ & 0,00 & $61,125.91$ & $173,218.49$ \\
Ger & co & $27,250.26$ & $14,339.40$ & $27,213.16$ & $2,679.42$ & $4,737.04$ & $27,250.26$ \\
& sp & $56,128.41$ & $40,166.79$ & $56,091.31$ & $4,188.25$ & $7,787.80$ & $56,128.41$ \\
& eu & $20,950.12$ & $9,131.30$ & $20,913.02$ & $2,107.99$ & $3,645.00$ & $20,950.12$ \\
Ned & co & $67,776.96$ & 0.00 & $50,402.23$ & 0.00 & $29,634.52$ & $20,644.56$ \\
& sp & $73,291.36$ & 0.00 & $55,916.64$ & 0.00 & $29,634.52$ & $20,318.19$ \\
& eu & $66,207.92$ & 0.00 & $48,833.20$ & 0.00 & $29,634.52$ & $22,832.97$ \\
Ita & co & $61,640.77$ & 0.00 & $36,917.06$ & 0.00 & $24,723.71$ & $61,640.77$ \\
& sp & $61,640.77$ & 0.00 & $36,917.06$ & 0.00 & $24,723.71$ & $61,640.77$ \\
& eu & $61,640.77$ & 0.00 & $36,917.06$ & 0.00 & $24,723.71$ & $61,640.77$ \\
Por & co & $25,126.79$ & $1,767.56$ & $7,242.08$ & 0.00 & $13,036.51$ & $25,126.79$ \\
& sp & $22,426.56$ & $1,007.76$ & $6,482.28$ & 0.00 & $13,036.51$ & $22,426.56$ \\
& eu & $21,503.12$ & 404.57 & $5,879.09$ & 0.00 & $13,036.51$ & $21,503.12$ \\
\hline
\end{tabular}

Spa $=$ Spain; Den $=$ Denmark; Fin $=$ Finland; Ger $=$ Germany; Ned $=$ The Netherlands; Ita $=$ Italy; Por $=$ Portugal.

co-current U-values in the country, sp-current U-values in Spain, eu-recommended U-values by Eurima. 
The application of the different methods in a compared manner enables us to state that those methodologies based on computer programs present limitations in terms of the information that they offer and the interpretation of the results. The LIDER program, in use in Spain, offers a percentage of energy efficiency for the building under study. This information is difficult to interpret and does not enable an evaluation of the impact of the measures for saving energy. It is in a second file that one can find specific data on the energy demand, losses and gains for the building under study. In the methodologies currently in use in Holland and Denmark, which also use computer programs, the quantity of information offered is greater; although, as in the case of Spain, the evaluation of the impact of the constructive improvements is complicated. However, the absence of information also affects methods based on spreadsheets. In Table 4, the factors shown as 0.00 correspond to factors that are not offered as a result once the process has finalised.

On the other hand, the freedom offered by the EPBD for the development of methodologies for the evaluation of the energy performance of buildings is reflected in the factors that each methodology considers for the calculation of the energy demand for cooling purposes. The differences found with regard to the quantity of energy demanded originate in the importance that each country gives to each of the factors considered in the process. Calculation temperatures, the influence of the infiltration of air and the precision with which the internal gains are calculated, are interpreted in a different manner according to the methodology considered.

The differences found are significant, in particular those results obtained upon calculating the energy gains using the methodologies currently in use in Finland, $173,218.49 \mathrm{kWh} / \mathrm{a}$ and in Portugal, between 21,503.12 and 25,126.79 kWh/a. The reason can be found in the precision and quantity of factors considered in the calculation in the case of Finland, which in addition does not consider the shell, and the use of a table that depends on the number of occupants and the surface area, as well as considering the shell, in the case of Portugal.

With regard to internal gains, we can appreciate a similar performance in the results obtained from the methodologies of Denmark $54,274.27 \mathrm{kWh} / \mathrm{a}$ and Finland 61,125.91 kWh/a, Italy 24,723.71 and Holland 29,634.52 kWh/a and Spain 13,830.89 kWh/a and Portugal, 13,036.51 kWh/a, from which we can conclude that there are similarities in the results obtained according to the geographical location of the country in question. We should point out the different importance that each country grants to the amount of energy gained through the apertures in the shell, with values that go from $5,879.09 \mathrm{kWh} / \mathrm{a}$ in the case of the methodology in use in Portugal, with the transmittance factors recommended by Eurima, and 76,714.54 $\mathrm{kWh} / \mathrm{a}$ in the case of the methodology in use in Finland.

Amongst the methods that have been analysed, there are examples that could be considered to be conservative, despite the fact that they penalise the overall energy performance of the building. The methodologies in use in Italy and Finland omit the loss of energy through the shell when calculating the net energy used for cooling purposes, taking into account only the internal gains and the 
gains from radiation through apertures. Thus, if we compare the methodologies in use in Italy and Holland, the former shows net energy for cooling purposes amounting to $61,640.77 \mathrm{kWh} / \mathrm{a}$, which coincides with the total energy gains. In the case of the latter, we get between $20,318.19$ and $22,383.97 \mathrm{kWh} / \mathrm{a}$ with gains between $66,207.92$ and $73,291.36 \mathrm{kWh} / \mathrm{a}$. This situation means that increasing the requirements of the transmittance factor, which thereby implies an increase in the quality of the shell of the building and, amongst other factors, of the thickness of the thermal insulation, is not reflected in the energy performance of the building. It is necessary to clarify, despite the fact that it is not the object of this study, that in the methodologies of those countries where the aforementioned situation occurs, the energy required for cooling purposes is not considered when obtaining the energy certification.

We should point out, as can be seen in Figure 3, that in those countries where energy losses are considered in the calculation process, increasing the transmittance factor in façades leads to opposing performance in the result of the amount of energy for cooling purposes.

In the case of the methodology in use in Germany, reducing the transmittance factor from 0.51 to $0.13 \mathrm{~W} / \mathrm{m}^{2} \mathrm{k}$ reduces the energy demand for cooling purposes from 56,128.41 to 20,950.12 kWh/a. The methodology in use in Portugal, which has the least demanding transmittance factor in the study group at $1.60 \mathrm{~W} / \mathrm{m}^{2} \mathrm{k}$, only reduces the amount of energy used for cooling purposes by $20 \%$, despite increasing the requirements of the transmittance factor by $75 \%$.

On the other hand, in the case of the methodology in use in Spain, increasing the requirements of the transmittance factor by $20 \%$ and therefore increasing the thickness of thermal insulation, hardly produces changes in the amount of energy for cooling purposes and even leads to an increase in same.

From an analysis of Figure 3 we can conclude from the relationship between the transmittance factors in façades, on axis $\mathrm{Y}$, and the energy required for cooling purposes, on axis $\mathrm{X}$, that it is the methodology in use in Germany that

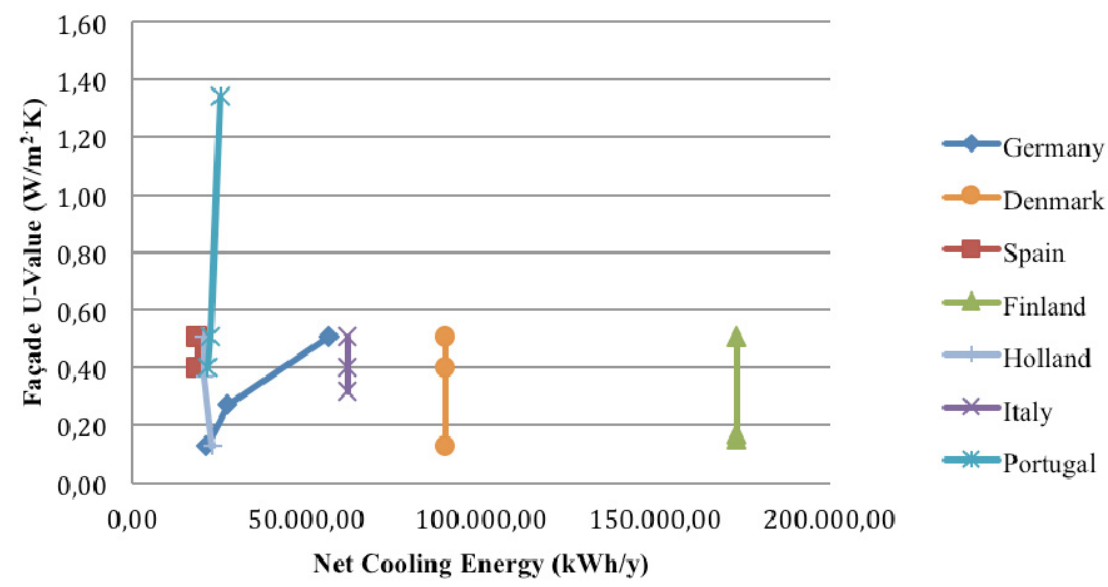

Figure 3: Relation between façade U-values and net cooling energy. 
best enables us to appreciate an improvement in the shell of a building in the process of calculating the energy required for cooling. A reduction in the transmittance factor from $0.28 \mathrm{~W} / \mathrm{m}^{2} \mathrm{k}$ (in use in Germany) to $0.13 \mathrm{~W} / \mathrm{m}^{2} \mathrm{k}$ (recommended by Eurima) produces a reduction in the amount of energy required for cooling from $27,250.26$ to $20,950.12 \mathrm{kWh} / \mathrm{a}$. The increase in the transmittance factor to that in use in Spain, $0.51 \mathrm{~W} / \mathrm{m}^{2} \mathrm{k}$, produces an increase in the energy required for cooling of a similar percentage, up to $56,128.41 \mathrm{kWh} / \mathrm{a}$.

In the same figure, the application of the variations in the transmittance factor to the methodologies in use in Spain, Holland and Portugal hardly produces changes in the amount of energy required for cooling purposes. This therefore creates doubt about the need for an improvement of the thermal shell of the building.

We can also see the performance of the methodologies that do not take into account energy losses through the shell in the calculation of the energy required for cooling. The results obtained from the application of the methodologies in use in Italy, Denmark and Finland offer the same amount of energy, despite significant variations being made to the transmittance factor.

\section{Conclusions}

The comparison applied to a case study of different methodologies for the evaluation of the energy performance of buildings shows the large amount of variables that have been adopted by the different EU countries during the process of implementation of the EPBD.

The variations in the energy demand shown by each of the methods are the result of the degree of precision and importance that each country gives to the different gains or losses of energy that can be considered in the calculation.

The methodologies adopted in some of the EU countries would create doubt as to the viability of an improvement of the shell from the point of view of reducing the energy demand for cooling purposes. An increase in the requirements of the transmittance factors, in some of the processes analysed, does not a priori produce improvements in the demand for energy for cooling the building, as the calculations do not take into account the gains or losses of energy that might be produced through the shell.

On the other hand, in those methodologies that do take into account for the purposes of the calculation the loss of energy through the shell, we see different energy performance. There are methodologies where increasing the requirements of the transmittance factors reduces the amount of energy needed for cooling, whereas in other methodologies the opposite occurs. The differences found in the evolution of the energy demand are the result of the need to find a balance in the thickness of the thermal insulation for summer and for winter. It would therefore be the prevailing climate in each country that would be the factor to consider for increasing or not the requirements of the transmittance factor and, therefore, the need for establishing or not constructive improvements in the shell of the building. 


\section{References}

[1] Ley 38/1999 de 5 de noviembre de Ordenación de la Edificación y Real Decreto 314/2006 de 17 de marzo de 2006 por el que se aprueba el Código Técnico de la Edificación.

[2] Directive 2002/91/EC of the European Parliament and Council, 16 December 2002, on energy efficiency of buildings.

[3] García Casals, Xavier. "Regulación y Certificación energética de edificios: Asignatura Pendiente en España”, Instituto de Investigación Tecnológica, IIT-04-0221, Universidad Pontificia de Comillas, 2004.

[4] Commission Delegated Regulation (EU) No 244/2012 of 16 January 2012 supplementing Directive 2010/31/EU of the European Parliament and of the Council on the energy performance of buildings by establishing a comparative methodology framework for calculating cost-optimal levels of minimum energy performance requirements for buildings and building elements.

[5] Real Decreto 235/2013, de 5 de abril, por el que se aprueba el procedimiento básico para la certificación de la eficiencia energética de los edificios.

[6] García Casals, Xavier. "Problemática de las referencias variables en la certificación energética de edificios". Libro de Actas Conama 9, Congreso Nacional del Medio Ambiente 2009. 2009, pp 69-81.

[7] Boermans, Thomas; Petersdorff, Carsten. "U-Values for better energy performance of buildings". Eurima (European Insulation Manufacturers Association) - Ecofys. Brussels, 2007.

[8] Spiekman, Marleene; Dijk Van, Dick. "Comparing Energy Performance requirements over Europe. ASIEPI - Assessment and Improvement of the EPBD Impact". Comisión Europea, Directorate-General for Energy and Transport, Brussels, 2008.

[9] European Commission. Energy. "Low energy buildings in Europe: current state of play, definitions and best practice". Brussels, 2009.

[10] CEN - European Committee for Standarization. CEN/TR 15615:2008. Explanation of the general relationship between various European standards and the Energy Performance of Buildings Directive (EPBD) Umbrella Document.

[11] Maldonado, Eduardo (coord.). "Implementing the Energy Performance Directive (EPBD)". Concerted Action Energy Performance of Buildings. UE. Brussels, 2010.

[12] Suomen Rakentamismääräyskokoelma 1976. Finland's National Building Code. Ministry of Environment, Finland, 1976.

[13] Suomen Rakentamismääräyskokoelma. Ministry of Environment, Finland, 2012.

[14] BBR-1961. Bekendtgørelse om ajourføring af Bygnings- og Boligregistret. Denmark, 1961.

[15] BR10. Bygningsreglementet 2010. Denmark's Construction Agency. Ministry of Economy and Business Affairs, Denmark, 2010. 
[16] Bygningers Energibehov. Statens Byggeforskningsinstitut, Aalborg Universitet. Denmark, 2011.

[17] EnEV 2009 - Energieeinsparverordnung für Gebäude. Bundesregierung, Germany, 2009.

[18] Gesetz zur einsparung von energie in gebäuden (enEG 1976). Bundesregierung, 22 July 1976, Germany, 1976.

[19] DIN V 18599:2007, Energetische Bewertung von Gebäuden Berechnung des Nutz-, End- und Primärenergiebedarfs für Heizung, Kühlung, Lüftung, Trinkwarmwasser und Beleuchtung. DIN - Deutsches Institut für Normung e. V. Germany, 2007.

[20] EPN, Energie Prestatie Norm 1995. Agentschap NL, Ministerie van Economische Zaken. The Netherlands, 1995.

[21] Bouwbesluit 2012. The Netherlands, 2012.

[22] NEN 5128:2004 $\mathrm{nl}$ - Energieprestatie van woonfuncties en woongebouwen - Bepalingsmethode. Nationale Normalisatie-instituut. The Netherlands, 2004.

[23] NEN 2916:2004 nl - Energieprestatie van utiliteitsgebouwen Bepalingsmethode. Nationale Normalisatie-instituut. The Netherlands, 2004.

[24] NEN 7120+C2:2012 nl - Energieprestatie van gebouwen Bepalingsmethode. Nationale Normalisatie-instituut. The Netherlands, 2012.

[25] NVN 7125:2011 nl - Energieprestatienorm voor maatregelen op gebiedsniveau (EMG) - Bepalingsmethode. Nationale Normalisatieinstituut. The Netherlands, 2011.

[26] Norma UNI TS 11300:2008. Risparmio energetico e prestazioni energetiche degli edifici. Italia, 2008.

[27] Decreto-Lei $n^{\circ}$ 80/2006, de 4 de Abril, aprova o Regulamento das Características de Comportamento Térmico dos Edifícios (RCCTE). Portugal, 2006.

[28] Yilmaz, Z. "Evaluation of energy efficient design strategies for different climatic zones. Comparison of thermal performance of building in temperate-humid and hot-dry climate", en Energy \& Buildings, n 39, 2007, pp. 306-316.

[29] EN ISO 13790:2008. Energy performance of buildings. Calculation of energy use for space heating and cooling. 